\title{
Role of histamine receptor blockade therapy and reflux esophagitis
}

\author{
J JOSEPH CONNON, MD, FRCPC
}

\begin{abstract}
JJ CONNON. Role of histamine receptor blockade therapy and reflux esophagitis. Can J Gastroenterol 1993;7(5):411-413. Multiple factors are involved in causing reflux esophagitis, the most important being transient relaxation of the lower esophageal sphincter, decreased esophageal acid clearance, and prolonged, frequent reduction of esophageal $\mathrm{pH}$. Successful treatment depends on decreasing acid secretion, reducing reflux and increasing acid clearance and gastric emptying. Sustained reduction of acid secretion is most important. Standard doses of $\mathrm{H}_{2}$ receptor antagonist drugs relieve symptoms in $60 \%$ of patients but heal erosive esophagitis in only $30 \%$. Increased healing rates can be obtained by higher doses of $\mathrm{H}_{2}$ receptor blocking drugs. Treatment should be continued for eight to 12 weeks using a twice daily schedule. Relapse is common following discontinuation of therapy.
\end{abstract}

Key Words: Acid, Esophagitis, $\mathrm{H}_{2}$ blockers, Pathophysiology, Treatment

\section{Rôle des inhibiteurs $\mathrm{H}_{2}$ et osophagite de reflux}

RÉSUMÉ: De multiples facteurs sont en jeu dans l'cesophagite de reflux, les plus importants d'entre eux étant la relaxation transitoire du sphincter cesophagien inférieur, la diminution de l'élimination de l'acide au niveau de l'cesophage et l'abaissement prolongé et fréquent du $\mathrm{pH}$ œsophagien. La réussite du traitement dépend de la diminution de la sécrétion acide, d'une plus grande élimination de l'acide et de l'augmentation de la vidange gastrique. La réduction soutenue de la sécrétion acide est la plus cruciale. Les doses standard d'inhibiteurs $\mathrm{H}_{2}$ soulagent les symptômes chez $60 \%$ des patients, mais n'assurent une cicatrisation de l'oesophagite érosive que chez $30 \%$. Des taux supérieurs de cicatrisation peuvent être obtenus avec des doses plus élevées d'inhibiteurs $\mathrm{H}_{2}$. Le traitement doit être poursuivi durant 8 à 12 semaines sur la base d'un schéma biquotidien. La rechute est fréquente, après l'interruption du traitement.
E EQUENT, BRIEF EPISODES OF GAS. troesophageal reflux are normal physiological events (1). A failure, either of the mechanisms preventing reflux damage or of factors increasing reflux, may create the disorder now termed gastroesophageal reflux disease (GERD). This disorder spans a spectrum of severity ranging from the occurrence of relatively infrequent hearthurn to the development of a severe erosive esophagitis and its complications.

Normally, excessive reflux of gastric contents into the esophagus is prevented by efficient contraction of the lower esophageal sphincter (LES), action of the diaphragmatic crus, the exertion of intra-abdominal pressure on the subdiaphragmatic segment of the esophagus, efficient esophageal clearance and efficient gastric emptying (2). The importance of transient relaxation of the (LES) in causing reflux is now accepted. Transient LES relaxation is a normal physiological event. These transient relaxations occur most commonly in the erect position and are inhibited by recumbency and by sleep. In patients with esophagitis, the frequency of transient LES relaxation is increased, especially at night, and is 
responsible for $70 \%$ of reflux episodes. Very low basal sphincter pressures of less than $5 \mathrm{mmHg}$ and transient increases in intra-abdominal pressure are responsible for the remaining $30 \%$ of reflux episodes $(3,4)$. Efficient clearance of refluxed material is also important in diminishing damage to the esophageal epithelium. The mechanisms responsible for clearance include: gravity; esophageal peristalsis; and neutralization of the thin film of fluid adhering to the esophageal epithelium by salivary bicarbonate, as well as bicarbonate secreted directly by the esophageal mucosa. There is evidence that abnormalities of esophageal and gastric emptying occur in patients with (EERD) and persist even after complete mucosal healing $(5,6)$.

\section{ACID SUPPRESSION}

It is generally accepted, especially in the light of recent data showing a successful response to treatment with omeprazole or high doses of histamine receptor blockers, that the major factor promoting esophageal mucosal damage is gastric acid. In patients with esophagitis resistant to the usual therapy, gastric acid secretion is increased and is more resistant to suppression (7-9). Contact time of the esophageal mucosa with the refluxed material is probably also important. It has been demonstrated by $24 \mathrm{~h} \mathrm{pH}$ monitoring that patients with only symptomatic reflux have multiple brief declines in $\mathrm{pH}$, whereas those with erosive esophagit is have multiple, prolonged reductions in $\mathrm{pH}$, especially at night (10). Although there is no doubt about the predominant role of acid, the action of pepsin may also be significant. The activity of pepsin is markedly enhanced when the $\mathrm{pH}$ falls below 2. Most studies have shown that reflux of bile is relatively unimportant in the pathogenesis of esophagitis (11). It has been suggested, by analogy with factors leading to gastric mucosal damage, that there may also be a deficiency in esophageal resistance in some patients, but such an abnormality has not been demonstrated.

It is clear that in order to treat (iERD) it is desirable to: increase the $\mathrm{pH}$ of the refluxed material; reduce the amount of reflux; restore sphincter pressure; and increase esophageal clearance and gastric emptying. No single drug can achieve all these effects but, fortunately, therapeutic efficacy can be achieved in the large majority of patients by reducing gastric acid secretion. In a multiple regression analysis of controlled trials of various agents reducing acid production, it was shown that healing correlated with an increase in $\mathrm{pH}$ above 4 and with the duration of treatment. A maintenance $\mathrm{pH}$ above 4 for $21 \mathrm{~h}$ predicted $100 \%$ healing of esophagitis at the end of an eightweek treatment period (12).

\section{INITIAL STUDIES}

Initial studies of histamine receptor blockade for reflux esophagitis were based on a false premise. It was believed at that time that a reduction of acid secretion comparable to that effective in healing gastric and duodenal ulcers would suffice for the healing of reflux esophagitis. However, it later became apparent that effective therapy required greater and more prolonged reduction of gastric acid production. Other study flaws included relatively small patient numbers in several of the studies and significant patient heterogeneity resulting from inadequate definition of disease severity, which resulted in several studies comparing 'apples and oranges'.

Overall, the $\mathrm{H}_{2}$ receptor blocker studies reported in the early and mid '80s showed no significant difference between the various drugs. Most of the studies related to cimetidine and ranitidine and the average symptomatic response rate was $60 \%$ but healing of erosive esophagitis occurred in only $30 \%$ of patients (13).

When the importance of greater acid suppression in healing esophagitis became apparent, a further series of trials was mounted using both larger doses of $\mathrm{H}_{2}$ blockers and increased dose frequency. These studies stratified patients according to endoscopically assessed grades of severity. Doses of 1200 to $1800 \mathrm{mg}$ ranitidine daily significantly reduced the number and duration of reflux episodes during a $24 \mathrm{~h}$ period (14). Using doses of this magnitude, it was demonstrated that ranitidine, $300 \mathrm{mg}$ qid, healed $75 \%$ of patients with grades II and III erosive esophagitis in eight weeks, compared with a healing rate of $54 \%$ using $150 \mathrm{mg}$ bid (15). Euler (16) demonstrated a healing rate of $81 \%$ using either ranitidine $150 \mathrm{mg}$ qid or $300 \mathrm{mg}$ qid, compared with a healing rate of $50 \%$ with placebo at the end of 12 weeks. Using famotidine, $40 \mathrm{mg}$ bid for 12 weeks, Festen (17) showed $75 \%$ healing of all grades of esophagitis; a healing rate of $50 \%$ was obtained in patients with grade IV esophagitis. A healing rate of $83 \%$ was obtained at 12 weeks with nizatidine, $300 \mathrm{mg}$ bid in patients with grade 1 to III esophagitis (18).

\section{MAINTENANCE STUDIES}

More than one-third of healed patients relapse following discontinuation of therapy with $\mathrm{H}_{2}$ blocking drugs (19). Relapse rates are related to the initial healing rates and therefore, not surprisingly, are higher following treatment with omeprazole compared with ranitidine (20). Most studies have shown that maintenance therapy with the usual doses of histamine receptor blockers do not prevent relapse (19, 21). However, Euler recently reported (in an abstract) that ranitidine, $150 \mathrm{mg}$ bid, reduced the endoscopic recurrence rate of esophagitis in 170 mild to severe patients from $70 \%$ to $40 \%$ after one year (22). An interesting outcome of the maintenance studies has been the observation of a lack of congruence between symptoms and endoscopic findings. Following treatment, Koeltz (19) demonstrated that $50 \%$ of healed patients were symptomatic whereas $40 \%$ of unhealed patients were asymptomatic.

\section{SUMMARY}

$\mathrm{H}_{2}$ receptor blockers are symptomatically effective in the majority of patients. There is some evidence that bid dosage is better than single dosage and, since healing rates continue to increase as therapy is prolonged, treatment should be continued for eight to 12 weeks. The initial dose regimen of the four available $\mathrm{H}_{2}$ blockers should 
be: ranitidine $150 \mathrm{mg}$ bid, cimetidine $300 \mathrm{mg}$ bid, famotidine $20 \mathrm{mg}$ bid, nizatidine $150 \mathrm{mg}$ bid. If symptoms fail to respond or recur rapidly following withdrawal of therapy, the patient should be referred for endoscopic assessment. Although healing of erosive esophagitis can be obtained in the majority of patients with a high dose/high frequency regimen of histamine receptor blockade, in the interest of both patient compliance and cost and efficacy, further treatment with omeprazole is recommended.

\section{REFERENCES}

1. Dent J, Dodds WJ, Freidmin RH, et al. Mechanism of gastroesophageal reflux in recumbent asymptomatic human subjects. I Clin Invest 1980;65:256.

2. Holloway RH, Dent J. Pathophysiology of gastroesophageal reflux. Gastroent Clin North America 1990;19:518.

3. Dent J, Holloway RH, Tuli J, Dodds WJ. Mechanisms of lower esophageal sphincter incompetence in parients with symptomatic esophageal gastroesophageal reflux. Gut 1988:29:1020.

4. Dodds WJ, Dent J, Hogan WJ, et al. Mechanisms of gastroesophageal reflux in patients with reflux esophagitis. N Engl J Med 1982;307:1547.

5. Singh P, Adamopoulos A, Taylor RH. Colin-Jones DG. Esophageal motor function betore and after healing of esophagitis. Gut 1992;33:1590-6.

6. MeCallum RW, Berkowitz DM, Lerner E. Gastric emptying in patients with gastroesophageal reflux.

Gastroenterology 1981; 80:285-91.

7. Ayres RCS, Ryan L, Robertson DAF, Smith CL. Treatment failure with $\mathrm{H}_{2}$ receptor antagonist and reflux esophagitis is due to diminished suppression of gastric acid secretion. Gastroenterology 1989;96:A20.

8. Johansson KE, Tibbling L. Gastric secretion and reflux pattern in reflux esophagitis before and during ranitidine treatment. Scand ] Gastroenterol 1986;21:779-88.

9. Rohertson DAF, Aldersley MA. Shepherd H, Lloyd RS, Smith CL. $\mathrm{H}_{2}$ antagonists in the treatment of reflux esophagitis. Gut 1987;28:946-9.

10. Van Trappen G, Janssens J. Pathophysiology and treatment of gastro-esophageal reflux disease. Scand J Gastroenterol 1989;24(Suppl 165):7-12.

11. Mittal RK, Reuben A, Whitney JO, McCallum RW. Do bile acids reflux into the esophagus? Gastroenterol 1987;92:371-5.

12. Bell NJV, Burget DW, Wilkinson J, Hunt RH. Gastro-esophageal reflux disease and gastric acid suppression. A meta-analysis to predict healing. Gastroenterology 1992;102:A40.

13. Meuweissen SGM, Klinkenberg-Knol EC. Treatment of reflux esophagitis with $\mathrm{H}_{2}$ receptor antagonists. Scand J Gastroenterol 1988;23(Suppl 146):201-13.
14. Jansen JBMJ, Baak LC Lamers CBHW. Are increasing doses of ranitidine helpful in reducing acid exposure of the esophagus in reflux esophagitis? Proc Dutch Soc

Gastroenterol Oet 1988.

15. Boyd AJS, Wood JR. H2 receptor antagonist in the treatment of reflux esophagit is. Scand ] Gastroenterol 1989;24(Suppl 171):136-43.

16. Euler AR, Murdock RH, Wilson TH Ranitidine is effective in healing erosive esophagitis. Gastrocnterology 1991;100:A61.

17. Festen HBM, Wesdorp ICE, Dekker W. The efficacy of famotidine $20 \mathrm{mg}$ hid versus $40 \mathrm{mg}$ hid in the treatment of erosive/ulcerative reflux esophagitis. Gastroenterology 1991;100:A63.

18. Berges W, Lux G, Simon B, Wienheck M, Quik R. A comparison of two doses of nizatidine in reflux esophagitis. Z Gastroenterol 1989;27:156A.

19. Koeltz HR, Birchler R, Bretholz A, et al. Healing and relapse of reflux esophagitis during treatment with ranitidine. Gastroenterology 1986;91:1198-205.

20. Sandbark S, Carlsson R, Fausa O, Lundell, L. Omeprazole or ranitidine in the treatment of reflux esophagitis. Scand J Gastroenterol 1988;23:625-32.

21. Kaul B, Petersen H, Ericksen H, et al. Gastroesophageal reflux disease. Scand J Gastroenterol 1986:21:139-45.

22. Euler AR, Murdock RH, Brotherton BJ, Silver MT, Parker SE. Ranitidine $150 \mathrm{mg}$ bid prevents erosive esophagitis tecurrences. Gastrocnterology 1992;102:65A. 


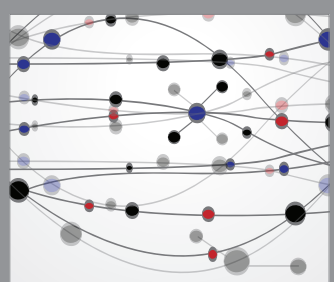

The Scientific World Journal
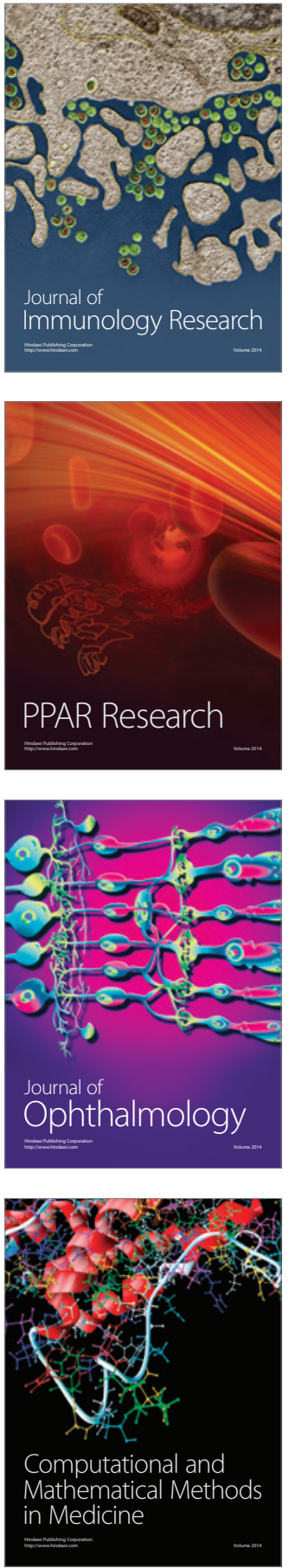

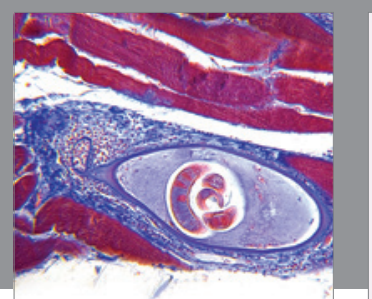

Gastroenterology Research and Practice

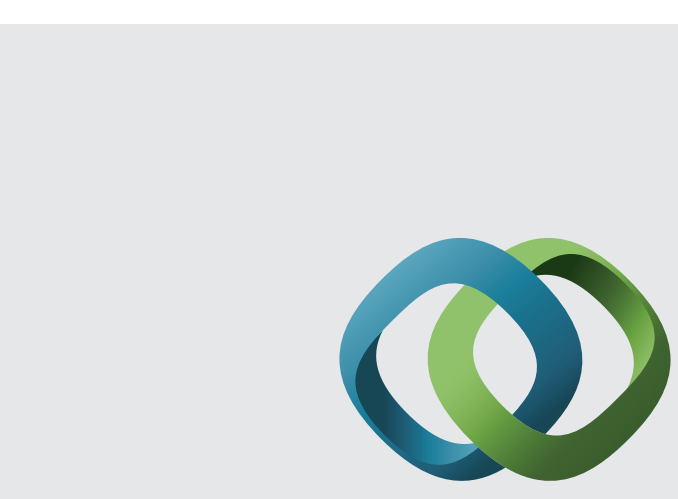

\section{Hindawi}

Submit your manuscripts at

http://www.hindawi.com
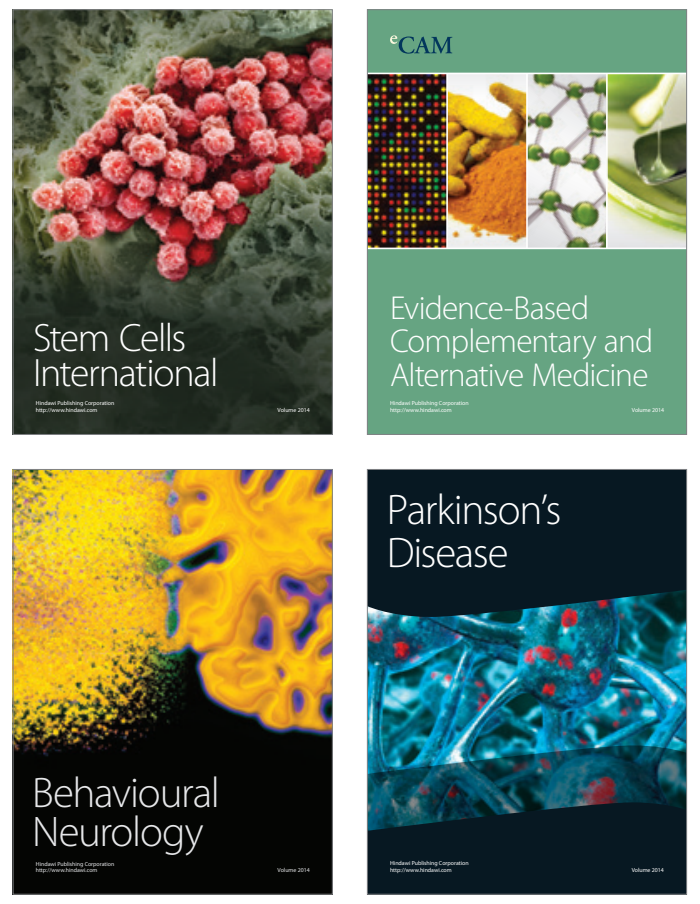
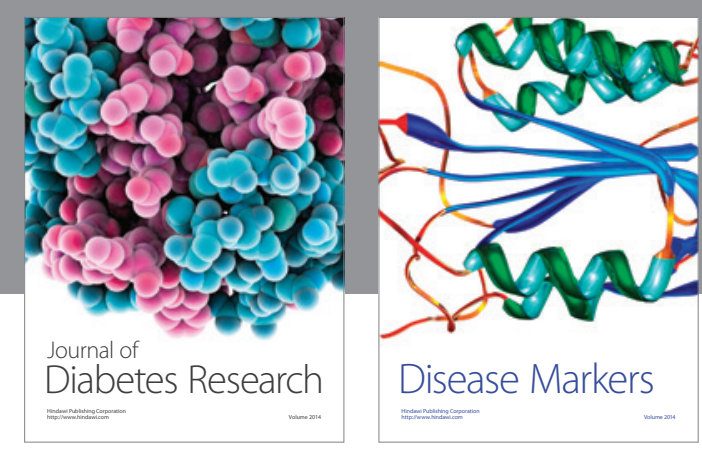

Disease Markers
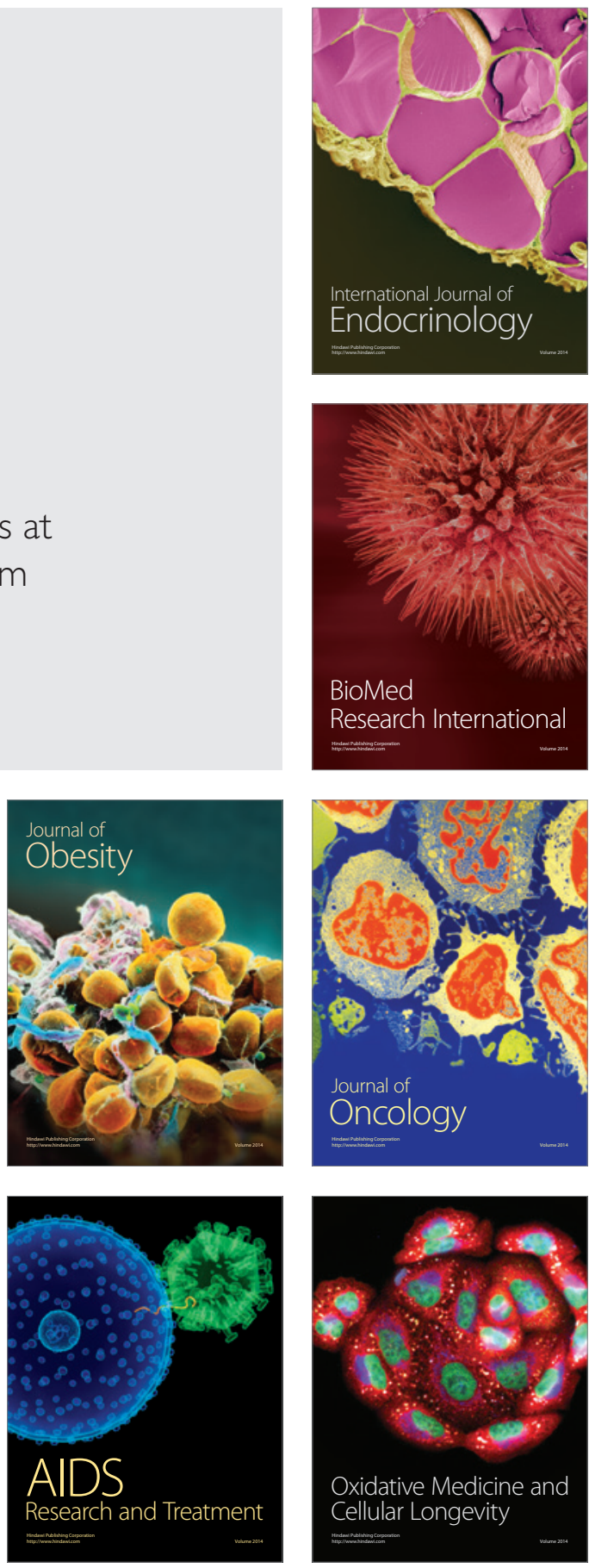